have extended to these students, many of whom are for the present quite without funds, cannot be left out of account. In regard to the Jewish students, who form a large proportion of the whole, and who are mostly Russian subjects studying at Liège or Ghent, valuable help has been received from the Central Jewish Committee.

This effort, however great the tax it imposes on the colleges, is worth making. It will enable Belgians who are medically unfit to go on active service, and Russians whose military service begins at the end of their university career, to obtain their professional qualifications during the war, and thus fill the depleted ranks of doctors and engineers in their respective countries. It will also spread a knowledge of English university education on the Continent, and not improbably make the University of London an international, as it is already an Imperial, centre of university education.

THE PRODUCTION AT WILL OF EITHER FUNGUS-GERMS, FLAGELLATE MONADS,

OR AMCEBAE FROM THE ULTIMATE
SEGMENTS OF SMALL MASSES OF
ZOOGLCEA.

$A \mathrm{~N}$ illustrated article dealing with this question of the heterogenetic oriyin from small Zooglœea masses of Fungus-germs, Monads, or Amœbæ, written by me, appeared in NaTure of November 24, 1904. That article was prepared at short notice in consequence of a short letter on "Archebiosis and Heterogenesis," which appeared a fortnight previously, and at a time when $I$ was not specially working at this subject. Of late I have been doing much work in this direction, and have made out many very important new points, and can now speak with more precision concerning the changes generally, and the modes of obtaining them.

My results were received with great scepticism, and no bacteriologist has been induced to attempt either to confirm or refute them. The possibility of "infection " has so dominated them, that they have refused to consider the question. Of late, however, three bacteriologists have accepted my request that they should allow me to demonstrate to them my position by their examination of actual specimens. This they did, separately, and as a result neither of them was able to doubt that the Fungus-germs, the Monads, and the Amœbæ were, in truth, derived from the ultimate segments of the Zooglœal masses; nor did they suggest that the very similar developmentai changes to be seen in hundreds of Zoogloeal masses taken from their respective scums could possibly be accounted for by "infection."

Only one of my friends had any interpretation to suggest in opposition to my own. He started the supposition that what appeared to be bacterial aggregates might "possibly," in spite of their appearance, not actually be of that nature. He suggested that, though taking the guise of bacteria, and though all were similar in appearance, they might nevertheless be some hitherto unknown progenitors of Fungusgerms, of Monads, and of Amœbæ which had aggregated as Zooglœal masses, and subsequently given rise to their respective products.

This wild supposition may, at all events, be taken as an indication that its author could not doubt the fact of the different products coming from the ultimate segments, or imagine that "infection" could account for what he had seen. It was started by one who was absolutely opposed to the very notion of heterogenesis. He was subsequently able to find absolutely no support for his "possibilities," and after a futile search frankly admitted that only bacterial Zoogloeas were known, apart possibly from others of an algoid type.

The current notion among bacteriologists concerning the nature and mode of origin of Zoogloeas is that adopted by R. Muir in the article, "Bacteriology," in the last edition of the "Encyclopædia Britannica" (vol. iii., p. I6I), in which he says :- "The Zooglœa is now known to be a sort of resting condition of the Schizomycetes, the various elements being glued together, as it were, by their enormously swollen and diffluent cell-walls becoming contiguous."

But bacteriologists do not seem ever to have examined the small masses that form in the scum on the surface of a hay infusion. I have been unable to find any reference to them, or of processes of segmentation occurring in any other Zoogloas. I cannot think that those with which we are now concerned are formed in the manner above indicated. All the evidence seems rather to show that as the bacteria rapidly multiply they also excrete the jelly-like gloeal material in which they are subsequently found to be imbedded.

\section{Preparation of the Infusions.}

One of the important new points recently ascertained is that I can prepare two small infusions at the same time from the same sample of hay, and by allowing one to infuse for three hours at a temperature of $90^{\circ} \mathrm{F}$., can feel confident that in the course of three to five days the ultimate products of segmentation of the Zooglœeas that form can be made to yield Monads or Amœbæ; while if the other is infused for the same time at $98^{\circ} \mathrm{F}$. no Monads or Amœbre will appear, and the ultimate Zooglœal segments, though formed, and very similar in appearance. will remain apparently stationary for eight to thirteen days, and then begin to show themselves as multitudes of brown Fungus-germs.

It is best to use comparatively new hay, and not that of the previous season. I take a small portion and having cut it into $\frac{1}{2}$-in. lengths, place it in $2-0 z$. beakers to which water is added just sufficient to cover it. The proportion of the two I have found to be a little more than 30 grains to the ounce of water. As soon as the infusions have been made they are filtered through No. o Swedish paper (so as to exclude encysted Kolpodæe and the great majority of Fungus spores) into common one-ounce porcelain pots, until they are about half-full-the depth of the infusion being then only a little more than half an inch. The scum which ultimately forms will be thin, and therefore much more favourable for examination than if it had been thick and formed over a greater depth of infusion. The covers are replaced on the pots, and the dates and temperatures at which the infusions have been made are marked thereon. These covered pots are then mostly kept at room temperature, $62^{\circ}-64^{\circ} \mathrm{F}$.

\section{Examination of the Scum or Pellicle.}

The pots are not usually opened until two days have elapsed, as it would be only during the last twelve hours that any very distinct scum begins to iorm, and that a few very small Zooglceas may be found scattered through it. By the end of the third day the Zooglœas may be very numerous, and will be found to vary much in size and shape. An example illustrating a rather later stage is shown in Fig. I, in which the little masses are seen to be extremely numerous. Many of these early Zooglœas already show primary processes of segmentation.

In order to examine the scum a small portion is taken up on the point of a scalpel and rotated off on to a drop of distilled water. If thereafter it should be desired to preserve the specimen some 5 per cent. 
formalin is run in, and the cover glass is ringed. But where there are brown Fungus-germs it is better to let the specimen remain in water, as the formalin, and also glycerin, would speedily remove their characteristic colour.

When some of these first-formed small Zooglœas are examined with a high power, it becomes obvious that they are simple aggregates of bacteria, such as may be seen in Figs. 2, A, and 3. Further, just the same kind of bacteria are to be seen within them as in the scum immediately around; and the bacteria from the scum of the infusion prepared at $90^{\circ} \mathrm{F}$. do not differ morphologically from those of the scum on the infusion prepared at $98^{\circ} \mathrm{F}$.

It must come to be a question whether the different products ultimately yielded by the two sets of Zoogloeas can in part be attributed $(a)$ to the fact that the constituent bacteria are actually different in the two cases, or $(b)$ to the fact that the slightly different (and far from lethal) temperatures at which the two infusions have been prepared, have sufficed to modify the physiological attributes of the same set of bacteria. The latter seems to me to be by far the more probable explanation, looking in part to the seeming morphological identity, and also to the possi-

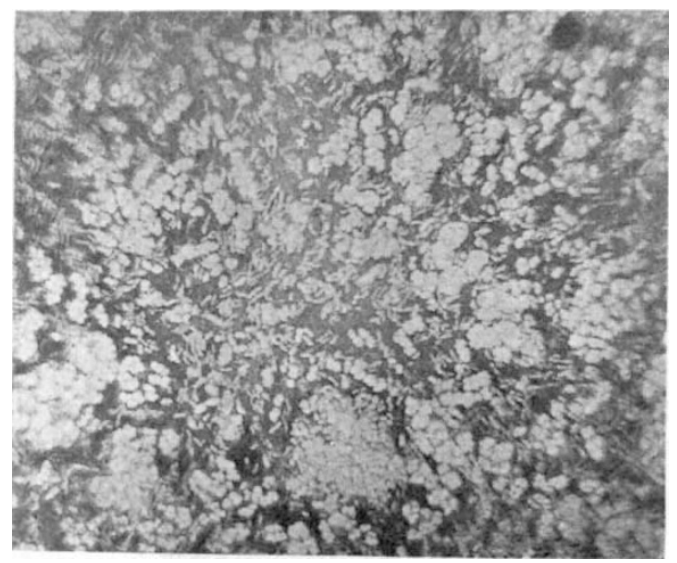

FIG. $x .-\times 200$.

bility that the exposure to the higher temperature of $98^{\circ} \mathrm{F}$. for three hours may have somewhat degraded the molecular structure of the bacteria, so that these particular aggregates are only eventually capablo of yielding vegetal rather than animal products, and that, too, after rather more than twice as long a period. Important facts in support of this conclusion will be reported later on.

It is, moreover, a very remarkable circumstance that almost until the ultimate products of segmentation are reached there seems to be no means of distinguishing by mere microscopical examination whether the Zooglœal masses are going to yield brown Fungusgerms, Monads, or Amœbæ. As they grow and develop, they all tend to segment into smaller and smaller portions; and after a time the constituent bacteria become hidden owing to molecular changes in the gloeal material. These are also shown by the segments becoming glistening and more refractive, and at the same time more receptive of logwood and other stains.

\section{Conversion of Ultimate Segments of Zoogloeas into Brown Fungus-Germs.}

In Figs. 2-5 are to be seen portions of some of the Zooglœas from pots contaning an infusion that had No. 2356 , VOL. 94] been prepared at $98^{\circ} \mathrm{F}$., and the scum on which subsequently yielded only Fungus-germs.

Fig. 2, A, shows a portion of one of the Zoogloeas at an early stage, in which the bacteria are still very

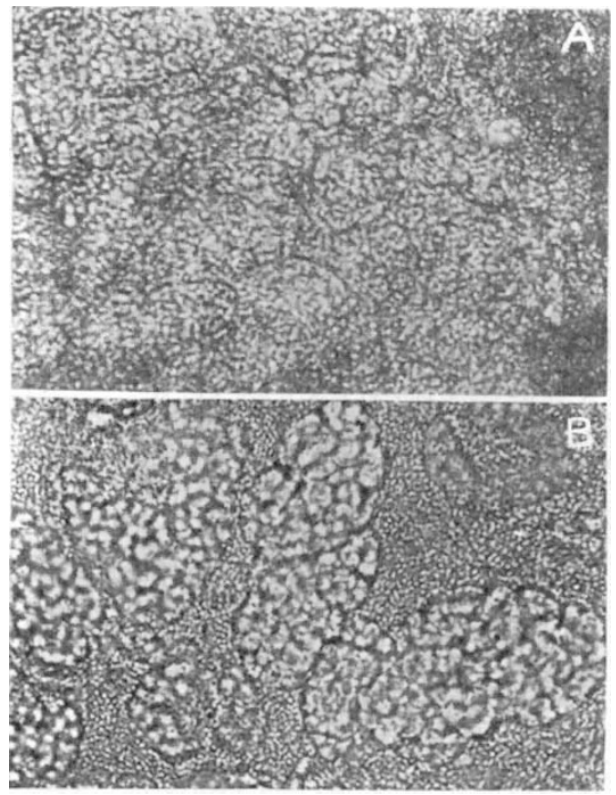

FIG. $2 .-\times 500$

distinct, though later they often tend to become more or less enlarged and altered in appearance. In Fig. 2, B, a later stage is shown in which much segmentation has taken place, where the bacteria are no longer recognisable, and the segments have assumed the glistening appearance already referred to

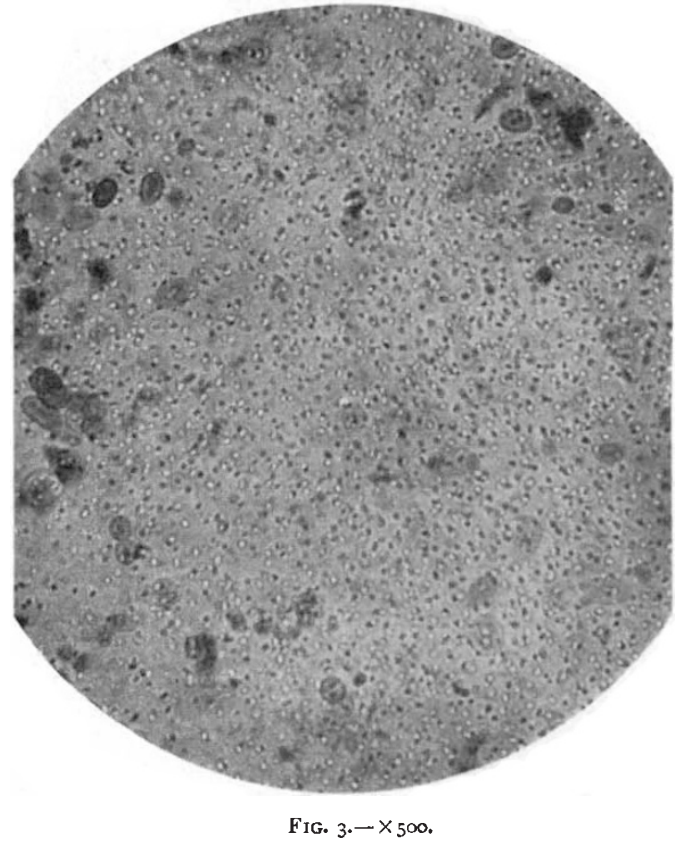

The date at which the change into brown Fungusgerms begins is subject to considerable variation, but this colour is rarely seen before the eighth or after the thirteenth day-the time needed being in part 
dependent upon the temperatures at which the pors are kept. ${ }^{1}$

The actual mode of production of the Fungusgerms from the bacterial aggregates may be seen in Figs. 3-5. A portion of a Zooglœa lightly stained with $C$. fuchsine is shown in Fig. 3, in which the bacteria are remarkably distinct, and where here and there they are becoming enclosed within distinct cellwalls. We see, in fact, a free cell-formation going on, in which the bacteria become the nuclei, and these nuclei undergoing division. Fig. 4 shows other stained specimens illustrating the mode in which segmentation progresses from multibacterial aggregates in $\mathrm{A}$ to multinuclear masses in $\mathrm{B}$, which lead on in $C$ to separate ultimate products in the form of nucleated Fungus-germs.

In Fig. 5 we have to do with unstained specimens gradually assuming a brown colour. In A the three pale masses show early stages in which the Fungusgerms are forming, in situ, in fairly large segments; while the dark masses around are aggregates of
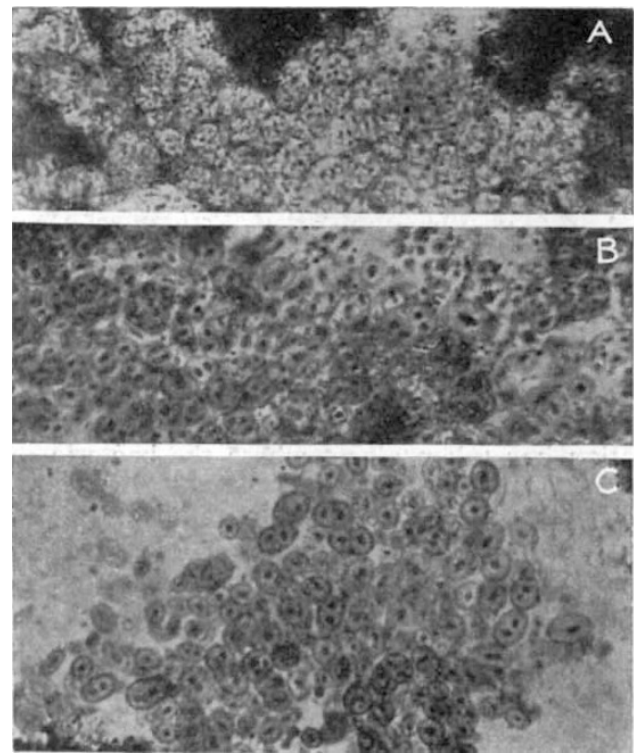

FIG. $4 .-X_{5}$ CO.

brown, fully formed Fungus-germs. In $\mathrm{B}$ we have a more ill-defined Zooglœa, in which careful examination will reveal portions becoming more and more distinct, until thev end with groups of large welldefined brown Fungus-germs.

We have here then a direct free formation of cells, the existence of which has so long been doubted, where bacteria constitute the nuclei, and the altered gloeal material the remaining portions of the cellprotoplasm. What is so plainly to be made out in Figs. 3 and 4 seems generally to occur when Fungusgerms are formed in and from Zooglœas; and the mode in which segmentation is so clearly shown to progress in Fig. 4 probably holds good for all other Zoogloeas, even when the ultimate products are of a wholly different order

In all cases the Fungus-germs produced in the manner I have shown, though they multiply to some extent so as to form small heaps or short chains, remain as such for very many days, and require to

1 Where the infusion has been made at a higher temperature, such as $100^{\circ}-\mathrm{I}^{3} 2^{3} \cdot \mathrm{F}$. the appearance of the brown Fingus-germs may he still further delayed. What I have to say in this communication re'ers only to the products from the Zoogloeas that may be found within the first fourteen days.

$$
\text { NO. } 2356 \text {, VOL. } 947
$$

be much coaxed in order to undergo further development with production of hyphæ.

Conversion of Ultimate Segments of Zoogloeas into Flagellate Monads.

Where the infusion has been prepared for three hours at $90^{\circ}$ instead of at $98^{\circ} \mathrm{F}$. the Zooglœas which form present no difference in appearance and in mode of segmentation from what has been represented in Fig. 2 .

There is, however, this remarkable difference, that such masses never assume a brown colour, and their ultimate products of segmentation begin to be visibly transformed in three or four rather than in from eight to thirteen days, and then they reveal themselves as rapidly increasing swarms of flagellate Monads.

These ultimate segments appear at first as little spherical, motionless bodies, such as are shown dispersed at the edge of a portion of scum in Fig. 6, A, and also aggregated as ultimate products of a small

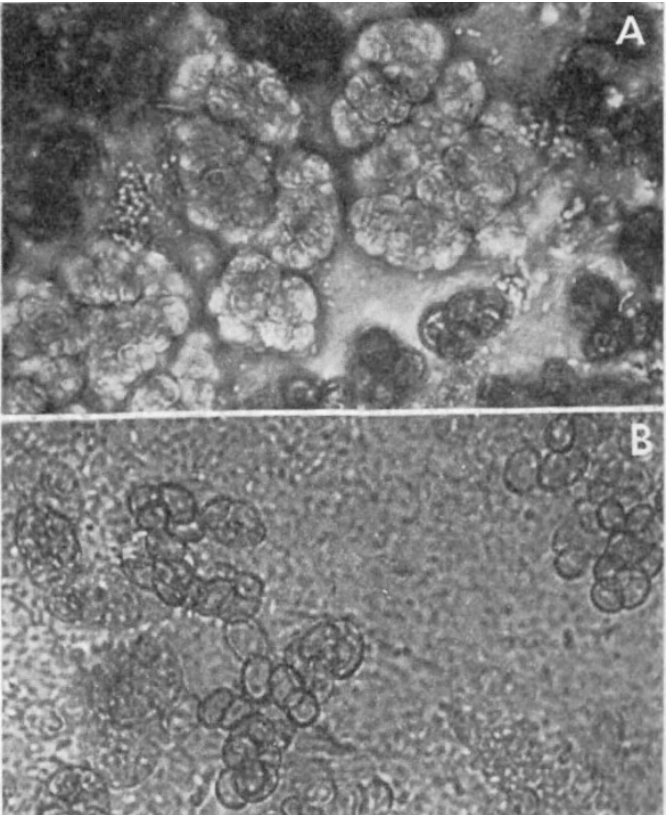

$$
\text { FIG. } 5 .-\times 7 \text { OO. }
$$

mass in $6, \mathrm{~B}$, though they are there somerwhat obscured by a few overlying bacteria. A smaller aggregate of motionless units is represented above, while below, before the running in of some formalin solution, some of the bodies shown were active Monads.

These Monads always contain a few granules, such as are shown in $6, \mathrm{C}$, in the lower body on the right, and a quite small nucleus is also frequently recognisable in such early units. Slight variations in size and shape of the Monads are met with from different samples of hay, just as different kinds of Fungusgerms are also produced. They have generally two flagella, though one of those that I succeeded in photographing (Fig. 6, C) has three. I have never previously been able to get any tolerable photograph of these Monads; this time I was to some extent successful with the aid of eosin. All other dyes or preservatives have proved useless, owing to the extremely delicate structure of the Monads. At times when a slide has been under examination for a rather long time, some of the Monads have become quiescent, and then I have often been able to recognise a contracting 
vacuole near the posterior extremity, rhythmically opening, and sharply closing about every twenty seconds.

Flagella, nuclei, and contracting vacuoles appearing in animal units independently of heredity, and as derivatives from chance bacterial aggregates, such facts now revealed supply us with marvels far surpassing what was previously seen in the way of origin of nuclei and free-cell formation during the genesis of brown Fungus-germs-though even these latter changes give the death-blow to Virchow's celebrated dictum, omnis cellula e cellula.

\section{Conversion of Ultimate Segments of Zoogloeas into Amoebae.}

This is perhaps a more interesting and remarkable transformation than either of the other two. When I last wrote on this subject I was altogether unaware of the nature of the differential conditions favouring the conversion into Amœbæ rather than into Monads. Now I have found that this production of Amcbæ can almost always be brought about by preparing the infusion at a temperature of $85^{\circ}$, rather than at
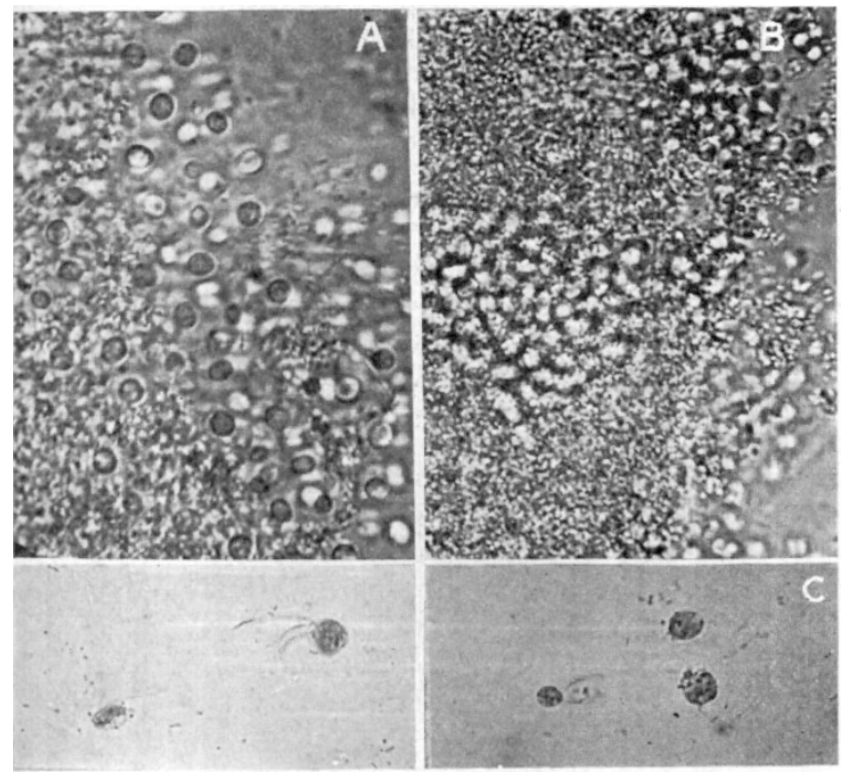

FIG. 6.-A and $\mathrm{B} \times 500 ; \mathrm{C} \times 700$.

$90^{\circ} \mathrm{F}$, and by subsequently keeping the pots at a temperature rather higher than that generally adopted. Sometimes, however, in such trials both Monads and Amœbæ are produced simultaneously.

The procedure mentioned generally leads to the production of a verv large number of Zooglœas, which have essentially the same bacterial constitution and mode of segmentation as have been met with in the other Zoogloeas, and which are represented in Fig. 2.

The transformed ultimate products of segmentation begin, as in the last case, to show themselves on or about the third day, while by the fourth and fifth days actual myriads of minute Amœbæ are to be seen in every portion of the scum taken up for examination, so that at last no traces of the very numerous Zooglœas from which they have been derived are to be found. These Amœbæ often at first have a single flagellum.

One of the final stages in such a resolution is shown in Fig 7, A, where the ultimate units, which are mixed with a few actual Amœbæ, are still pretty closely aggregated. In a few of them quite small nuclei are shown, though these are much smaller than what are

NO. 2.3.56, VOL. 947 generally to be seen in embryo Fungus-germs just stparated from a parent mass. The latter are also usually more ovoid, and have much more well-defined outlines.

A few of the myriads of $A$ mœbæ as they appear in the formalin solution are represented in $7, B$. The great crowds of Amobæ produced soon lead to conditions unfavourable for their existence, so that after another two days they will generally be found to have become encysted, as represented in Fig. 7, C.

Whether altered bacteria again furnish the nuclei of the finished products cannot be positively stated. The nuclei are always rather large in embryo Amobæ, and distinctly larger than in young Monads.

A point of great importance in reference to what I have said concerning the comparatively sudden appearance of great swarms of small Amcebre is the fact that such organisms can only rarely be seen to undergo division when immersed in fluids. I have long expressed this view, and now find it supported
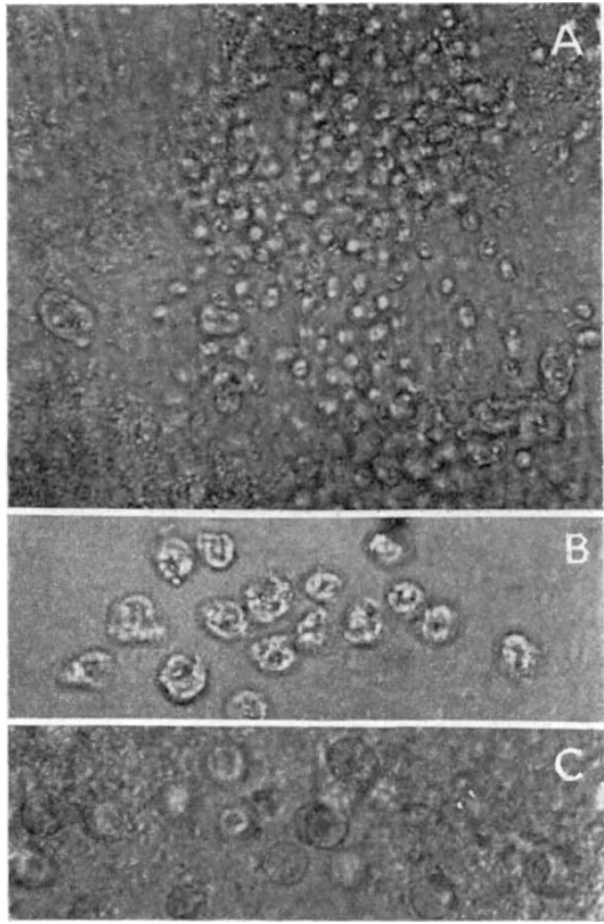

FIG. 7. $-\times 500$

by the latest workers on these organisms, namely, J. W. Cropper and A. H. Drew, in their recently published "Researches into Induced Cell-Reproduction in Amœbæ." The rapid appearance, therefore, shown to occur of myriads of minute Amcebæ would be quite inexplicable by ordinary processes.

In what has been said dctails have been given which will almost certainly lead, at will, to the productiont either of Fungus-germs, of Mionads, or of Amœbæ. I have already expressed the opinion (p. 462) that we have not necessarily to do with different bacteria in these cases, but rather with the same bacteria differently modified by the prolonged, though comparatively slight, differences of temperature maintained during the production of the infusions.

The recent access of cold weather has enabled me to confirm this, and has, moreover, shown that the temperature at which the pots are kept is only a little less important than the variations in temperature at 
which the infusions are prepared. I have found, for instance, that infusions prepared at $90^{\circ}$ and $85^{\circ} \mathrm{F}$. respectively, will no longer yield Monads or Amœbæ if the pots are from the first kept at a temperature of $50^{\circ}-54^{\circ} \mathrm{F}$. Then, in each case, as a rule, only brown Fungus-germs begin to appear after eight or more days, instead of the Monads or Amœbæ which would have appeared had the pots been kept at the higher temperatures previously indicated.

Here then we have the revelation of still more astounding facts, since it seems to be shown that Amœbæ, Monads, and Fungus-germs are actually interchangeable products, capable of being derived from similar bacterial aggregates, under the influence of slight but well-defined differences of temperature.

\section{A Few New Details Concerning Some Tube} Experiments.

In a previous communication to NATURE for January 22 of this year I gave some account of my experiments with saline solutions in sterilised tubes, tending to show that living matter is still appearing de novo on the surface of the earth, seeing that under the very restrictive conditions necessitated by these experiments there was abundant evidence to show that Bacteria, Torulæ, and simple Moulds have repeatedly come into existence.

I stated that my experiments had been repeated in Paris with positive results by Albert and Alexandre Mary. They not only obtained organisms from their tubes, but caused them to multiply in different culture media. $^{2}$ My experiments were also repeated in New York by Drs. Jonathan Wright and MacNeal. After some negative and some doubtful results, they succeeded last year, among a few other successes, in producing crowds of organisms in every one of a set of twelve tubes, containing colloidal silica and other materials which I had sent them. At first they felt strongly of opinion that the results obtained from the first of these tubes, in which, as they said, unquestionable organisms were found in "enormous numbers," must have been due to the pre-existence of organisms in the materials used. But after careful examination of the materials they found no support for this supposition, admitted that they could not take refuge in any other, and added, "we have no suggestion to make other than your interpretation, and, indeed, we desire to be entirely non-committal as yet."

These experiments were undertaken by Dr. Wright, as he told me in his first letter asking to be supplied with some of the actual materials used by me, in consequence of his "sincere desire to ascertain the truth"; but only a few weeks after they had found unmistakable confirmation of my results, I received a letter informing me that he and his colleague were not intending to pursue the investigation. One reason alleged for their relinquishment of the investigation at this particular juncture was their non-success, in the few, and only slightly varied, attempts made to cause the organisms to grow in culture media.

Dr. Wright has, however, been good enough to send me some of their notes and unopened tubes, and amongst them I have received and opened three of the twelve tubes in question. On examination the organisnis contained in each of them have been similar to those found in the first tube, specimens of which had been sent to me. In others, opened in New York, I am told the organisms have also been similar.

In Fig. 8, $\mathrm{A}$ and $\mathrm{B}$, two of the many larger organisms found by me are shown. They are of a kind new to me, not corresponding quite either with

2 See Le Medecin (Brusseis), Octoher $\neg 1$, 1913, and January 15, I914.

NO. 2356 , VOL. 947
Streptothrix or Crenothrix to which they seem most allied. In Fig. 9, A, one of the numerous early forms of such an organism, is shown; while in Fig. 9, B. we have a highly magnified reproduction of one of the many small masses which were found, similar to one which is to be seen in Fig. 8, A. In this mass,
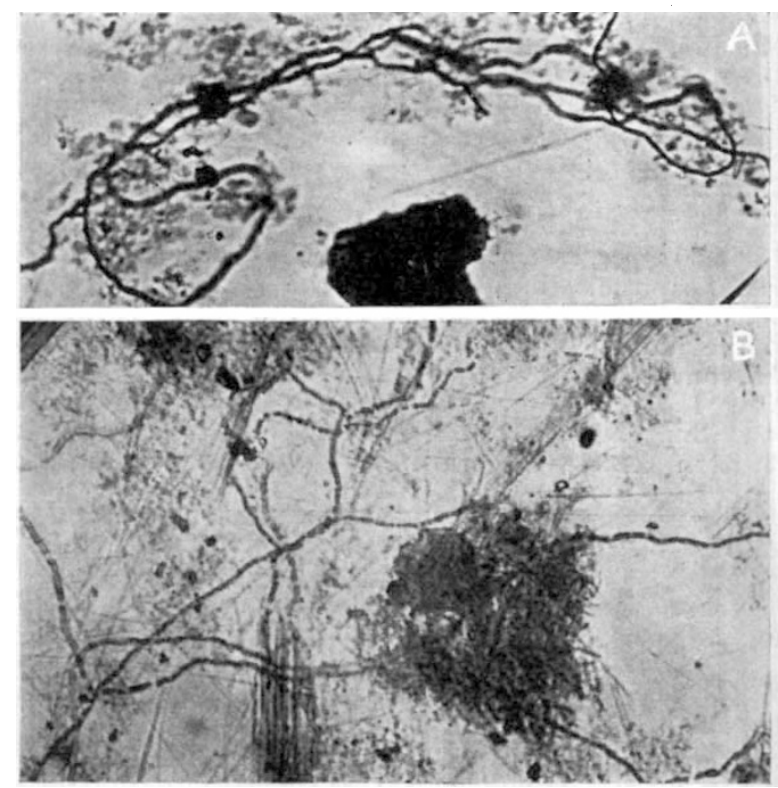

F1G. 8. $-\times 350$

among crowds of bacilli, there seem to be also many embryonic forms of the large organism.

I handed the last of these tubes to Aubrey $\mathrm{H}$. Drew, ${ }^{3}$ as he kindly undertook to try to develop the organisms. He has been successful, with the aid
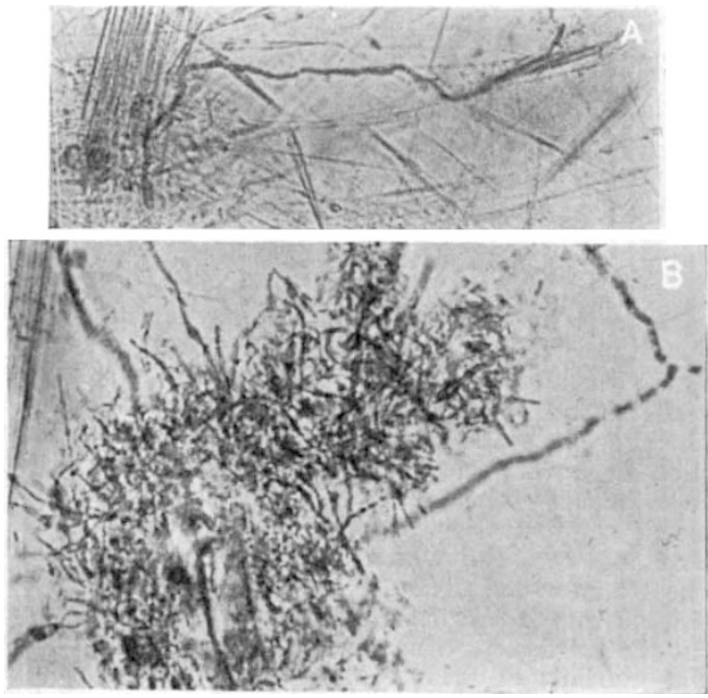

Fig. 9. $-\mathbf{A} \times 530 ; \quad \mathrm{B} \times 700$

of tyrosin and other auxetics, in cultivating the bacilli, more or less freely, in six different media, but not the large organism. The bacillus, too, seems to be strange; he has tested it in various ways and its

3 Joint-author with Dr. J. W. Cropper of "Researches into Induced CellReproduclion." (Murray, 19I4.) 
behaviour, he tells me, is not in accord with any known form. He says: "It is large, Io to $I_{5} \mu$ long, and shows a strong tendency in fluid cultures to grow into filaments, but I have not observed any branching." It is gram-positive, stains with difficulty, and "its most characteristic feature is a brilliant lemon yellow growth on auxietic agar.'

I should like to refer to one other recent experience. In June $26-28$, I9I2, I prepared and sterilised - six tubes containing a yellow solution composed of 3 drops of sodium silicate and 8 drops of liquor ferri pernetratis to the ounce of water. Five of these tubes were opened and their contents examined after periods ranging from six to nine months, and in each embryo Torulæ and other torula-like bodies, together with a few very minute mycelia of indeterminate types, are recorded by my notes to have been found. The sixth tube (No. 4r6) had been most of the time in the incubator, and was not opened till August 2 of this year-that is, more than two years after its preparation. Some previous experiences induced me to

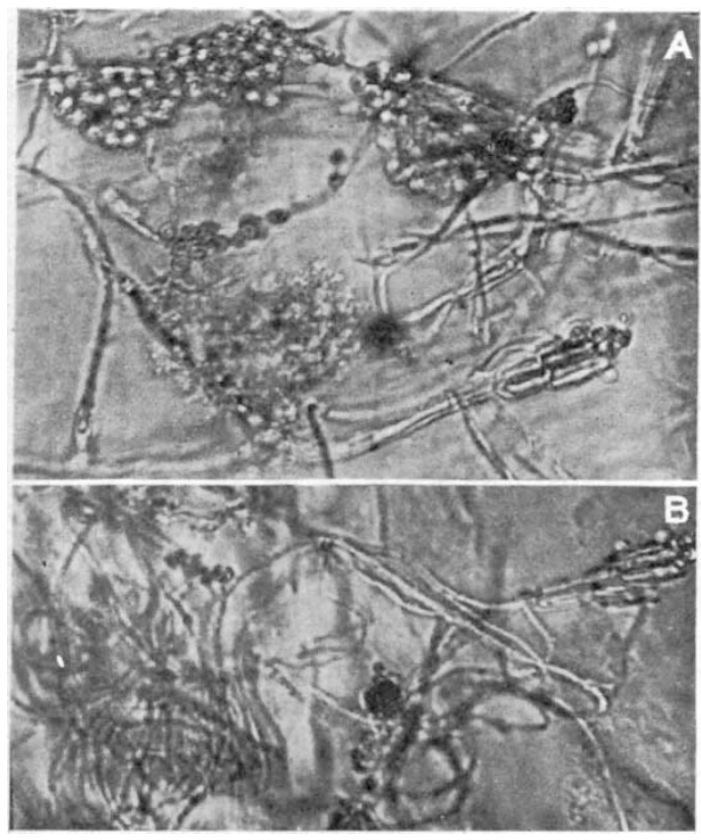

Fig, 10. $-\times 700$

make such a trial. On opening the tube, in which there was only a very small amount of deposit, I obtained the whole of it in two dips with a pipette (the centrifuge used afterwards showed only a few shreds, granules, and minute glass splinters). The contents of the dips revealed many of the same torulalike bodies as had been found in the other tubes, and also "four masses of minute mycelium issuing from aggregates of minute spherical and ovoidal germs, together with granular matter, in part seemingly composed of typical cocci and short bacilli.' With the Moulds, as shown in Fig. Io, A and B, there were masses of spherical spores with a central dot in each, together with small heads of fructification of Penicillium type bearing similar acrospores.

From a very similar solution contained in four other tubes, prepared on May $17-19$, I9I2, in three, which were opened at periods varying from seven to ten months, the spores and mycelium of a mould of Oospora type were found by myself and others. The fourth tube was kept for nearly seventeen months NO. 2356, VOL. 94] before it was opened, and two months before that date two obvious tufts of mould could be seen at the bottom of the tube, one of them nearly half an inch in diameter. When this tube was opened in Prof. Hewlett's laboratory, we saw that the growth was again a mass of Oospora * with the same characteristic spores as had been previously found. All this set of tubes had been exposed to light during the first six months, while the others had been in the incubator.

\section{Concluding Remarks.}

Many critics of my tube experiments have been incredulous either as to the organisms found in the tubes being really organisms, or else as to their being living and actually engendered within them. They found it difficult to reconcile with ordinarily entertained notions the idea that organisms like bacteria and Torulæ, to say nothing of Moulds, could be products of so-called "spontaneous generation."

Let such critics spend two or three weeks only in examining the developmental changes in the Zoogloas formed in a hay scum, and see how much many other cherished preconceptions will be upset. Are they ever likely to do it? Well, let them bear in mind that three bacteriologists to whom I have demonstrated these changes were unable to doubt that the Fungus-germs, the Monads, and the Amœbæ were actually derived from the ultimate products of segmentation; and, further, that they were unable to suggest "infection" as an hypothesis that could possibly account for the many hundreds of similar changes taking place simultaneously in each fragment containing the different sets of Zooglœa.

When they have seen similar results themselves, what attitude can the critics take? If they see animal products, such as Monads and Amœbæ, taking origin from aggregates of primordial vegetal units like bacteria, and are compelled to recognise that such Monads, altogether independently of any possible inheritance, are enabled to throw out flagella, to come into being provided with a nucleus, and to develop actively functioning contractile vacuoles, will they still adhere to all their preconceptions, or will they rather admit their previous ignorance of nature's potency in this as well as in many other directions?

In a recent able article ${ }^{5}$ on "Science and the Limits of Belief," Sir Ray Lankester dwells very forcibly upon "the importance of knowledge based securely on xperimental demonstration and the examination of actual things." As he says : "It is precisely by the refusal to discuss possibilities, and by being at the same time willing and anxious to receive and verify tangible demonstration of a fact, however improbable it may appear," that all progress in science has ever been made. With this I absolutely agree; and can only trust that critics generally will adopt a like opinion.

Archebiosis is a process that always takes place beyond our ken, seeing that it must begin with mere molecular collocations, gradually going on to the formation of particles of an ultra-microscopic order. And the only explanation that seems possible of the growth of such particles into organisms like those found in the tubes, as well as of the appearance of the heterogenetic products that we have seen proceeding from Zooglœal segments, is to fall back upon an explanation which is generally admitted to account for all the known forms of crystalline matter. Molecular constitution, combined with the influence of the environment, is what we have to appeal to there; and, as Herbert Spencer over and over again insisted, the forms and structures of organisms, under the influence

4 As shown bv Fig. 4, in NATURe for January 22, 1914.

5 In the R.P.A. Annual for 1915 (recently published 
of what he termed "organic polarity," must be dependent upon like causes. In accounting for the lower forms of living matter, therefore, we may suppose, as he says, ${ }^{6}$ that their "organic molecales of each kind, no matter how complex, have a form of equilibrium in which, when they aggregate, their complex forces are balanced."

\section{H. Charlton Bastian.}

\section{SMITHSONIAN GEOLOGICAI EXPLORA- TIONS.}

$\mathrm{D}^{\mathrm{U}}$ RING the past year, the Smithsonian Institution was represented in the field by nineteen parties and individuals engaged in the collection of data relative to astrophysics, geology, biology, and anthropology, besides nine representatives of the Bureau of American Ethnology, who secured information relative to the American Indian. While most of the exploration occurred in the United States, considerable work was carried on in Canada, the West Indies, Peru, Switzerland, Borneo, Cashmere, Egypt, Greece, and Italy.

A recent publication of the institution describing the various explorations, includes a report on the Palæontological field-work of the secretary, Dr. C. D. Walcott, in the Canadian Rockies, near the Robson Peak district in British Columbia and Alberta, and in Field, British Columbia. The mountainous scenery in the former region is quite alpine in appearance, including snow-capped and glacier-covered peaks which tower 7500 to $9800 \mathrm{ft}$. above Lake Kinney, itself some $3000 \mathrm{ft}$. above sea-level. On this trip Dr. Wal cott's party approached from the west in order to study the invertebrate fossils in this section, which he considers one of the finest in the world. At the base of the mountain at Lake Kinney, there exist fossil beds, $4000 \mathrm{ft}$. or more in thickness, where a number of important ancient Cambrian fossil fauna were secured, as well as many examples of the species found in 1912. At Field, work was carried on in the great Cambrian fossil quarry, where, after blasting out the solid beds to a depth of $22 \mathrm{ft}$., a fine collection for the U.S. National Museum was secured.

Another geological research party was also in the field for fossils, but, instead of the very early forms of life sought by Dr. Walcott, this second party, under the direction of Mr. J. W. Gidley, was in search of fossil mammals from a later epoch. In this connection, the party again excavated in the Pleistocene cave deposit near Cumberland, Maryland, discovered in I912, and found many new forms of mammals, and more complete remains of several species represented in the first collection solely by jaw fragments. The collection now numbers about 300 specimens, which represent forty or more distinct types of hitherto undescribed animals, many of which are now extinct, including the bear, peccary, wolverine, badger, martin, porcupine, woodchuck, dog and the American eland-like antelope. Other specimens found in less complete form were the mastodon, tapir, horse, and baaver, besides several smaller rodents, shrews, and bats. All these different animal remains occur intermingled and comparatively thickly scattered through the deposits of this ancient limestone cave, which was exposed by a cut made by the Western Maryland Railroad, and reported to the museum by Mr. Armbruster. Mr. Gidley is pursuing his studies in idertifying these different remains, and expects to continue his excavations from time to time.

Mr. C. IV. Gilmore, of the National Museum, con-

" "P.inciples of B:ologv" (revised edition, 1878), vol. i., Appendix D, p. 704 .

NO. 2356, YOL. 94$]$ ducted explorations in the north-western part of Montana, where some vertebrate fossil bones were discovered by a member of the Geological Survey in 1912. A total of more than 500 separate fossil bones was collected, among them a nearly complete skeleton of a new Ceratopsian or horned dinosaur, the smallest known of the great horned reptiles, and the first to be found having a complete articulated tail and hindfoot. Another find was a partial skeleton of the new Trachodont or duck-billed dinosaur, recently described from specimens obtained in Canada.

Dr. R. S. Bassler spent some time in the Appalachian Valley of Maryland studying the post-Palaozoic geologic history of the region as indicated by the present surface conditions, under the auspices of the U.S. National Museum, and the Maryland Geological Survey.

Another field research party which concerned the collection of fossils was maintained in Illinois by $\mathrm{Mr}$. F. Springer, in connection with the preparation of his monograph on the fossil crinoidea, and to add to the museum collections of these fossil invertebrate marine animals. The field-work was undertaken in co-operation with the geological work of the State of Illinois, in order that the horizons from which these fossils were taken might be definitely determined. This resulted in securing several large cases of material, among which were several very large slabs containing numbers of specimens.

\section{UNIVERSITY AND EDUCATIONAL INTELLIGENCE.}

Dr. E. G. Fearnsides, Miss F. M. G. Micklethwait, and Dr. E. P. Poulton have been elected to Beit Memorial Fellowships for Medical Research. Each fellowship is of the annual value of $25 \mathrm{ol}$.

THE third annual conference of educational associations will be held from January 4 to January 9 , I915, at the University of London, South Kensington. The inaugural address on the principles of educational science will be given by Bishop Welldon. In addition to the addresses and discussions in connection with the meetings of the Geographical Association, to which attention was directed in our issue of last week, mention may be made of the following contributions to the conference. At the meeting of the Froebel Society on January 4 Prof. J. J. Findlay will speak on educative toys and apparatus. On January 5 the Rev. Canon Masterman's presidential address to the Teachers' Guild will be on education for national service. The Provisional Committee for the Development of Regional Survey will meet on January 6 , and a number of speeches will be delivered on regional survey in relation to education. During the evening of this date the School Nature Study Union will meet, and Mr. E. E. Unwin will speak on nature-study and the teacher. On January 8 the Science 'Teachers' Association holds its meeting, and Miss Muriel Robertson will speak on some sleeping sickness problems in Uganda; and on the same day Dr. G. R. Parkin will address the Association of Assistant-mistresses on the responsibilities of Empire.

THE annual Convocation of the Allahabad University for conferring degrees was held in November. The Chancellor, Sir James Meston, delivered an address which is reported in the issue of the Pioneer Mail for November 20. Towards the end of his remarks he said :- " My sole aim is the greater efficiency of our University. Now there are two kinds of efficiency. One kind, wrongly so called, seeks for a mechanical perfection, an official symmetry, a standardising of work and ideals with little thought 